\title{
ХІРУРГІЧНЕ ЛІКУВАННЯ ЗОБУ
}

\author{
О. П. Ковальов, О. М. Люлька, І. І. Нємченко, В. І. Ляховський \\ Українська медична стоматологічна академія, м. Полтава \\ SURGICAL TREATMENT OF GOITER \\ O. P. Kovalyov, O. M. Luhlka, I. I. Nemchenko, V. I. Lyakhovskyi \\ Ukrainian Medical Stomatological Academy, Poltava
}

\begin{abstract}
Реферат
Проаналізовані результати хірургічного лікування 606 хворих з приводу різних форм зобу. Відображені показання до операції, оперативне втручання, новітні хірургічні технології. За вузлового і дифузного токсичного зобу (ДТЗ) перевагу віддають радикальним методам операцій. Застосування екстрафасціальних маніпуляцій на щитоподібній залозі (ЩЗ) та прецизійної техніки дозволяє зменшити вірогідність ушкодження під час операції гортанних нервів і прищитоподібних залоз та частоту післяопераційних ускладнень.

Ключові слова: щитоподібна залоза; зоб; хірургічне лікування.

\section{Abstract}

Results of surgical treatment of 606 patients, suffering various forms of goiter, were analyzed. Indications for operation, operative procedures itself, new surgical technologies are noted. Radical methods of operations are predominantly used for nodal and diffuse toxic goiter. Application of extrafascial manipulation on the thyroid gland and precise technique permits to reduce the probability of damage during operation of laryngeal nerves and parathyroid glands and the postoperative complications rate as well.

Keywords: thyroid gland; goiter; surgical treatment.
\end{abstract}

В Україні щороку виконують майже 12000 операцій на Щ3 [1]. Зміни поширеності та структури захворювань Щ3 зумовлені багатьма чинниками, зокрема, метаморфозами екологічного середовища. Останнім часом спостерігають зменшення частоти виявлення ДТЗ та збільшення вузлових форм зобу, з яких близько 5\% - це злоякісні пухлини [2].

Багато питань лікувальної тактики за різних форм зобу дискусійні, що пов'язане, передусім, з показаннями до хірургічного лікування, особливостями оперативної техніки, обсягом оперативного втручання [3-6].

В останні роки в структурі показань до операції на ЩЗ переважають онкологічні, резекційні методи операцій поступаються радикальним. Операції на ЩЗ пов'язані з можливістю ушкодження так званих "структур ризику": нижніх гортанних нервів (НГН), зовнішньої гілки верхніх гортанних нервів (ВГН), прищитоподібних залоз. Частота специфічних післяопераційних ускладнень залежить від обсягу та методу втручання, досвіду хірурга, використання відповідних технічних засобів та підходів [7 - 9].

Мета дослідження: проаналізувати результати оперативного втру- чання на Щ3 в різні періоди, визначити оптимальну хірургічну тактику.

\section{МАТЕРІАЛИ I МЕТОДИ ДОСЛІДЖЕННЯ}

Наведені результати хірургічного лікування 606 хворих з приводу різних форм зобу у хірургічному відділенні Другої міської клінічної лікарні м. Полтави - клінічної бази кафедри хірургії № 1 за період з 2002 по 2016 р. Вік хворих від 18 до 79 років, у середньому $(57,8 \pm 7,48)$ року. Чоловіків було 65 (10,7\%), жінок - 541 (89,3\%). Вузловий зоб з одного боку спостерігали у 187 (30,9\%) пацієнтів, багатовузловий - у 322 $(53,1 \%)$, токсичний багатовузловий - у 30 (4,9\%), тиреотоксичну аденому - у 10 (1,7\%), ДТ3 - у 57 (9,4\%).

Погляди на показання до хірургічного лікування зобу, методику і характер оперативного втручання 3 часом змінювалися внаслідок змін структури захворювань під впливом екологічних чинників, особливо після Чорнобильської катастрофи, а також впровадження новітніх хірургічних технологій та здобуття власного досвіду.

В останні роки використовуемо клінічні протоколи ведення пацієнтів 3 хірургічними захворюваннями ендокринної системи [10].
Узагальнюючи ці вимоги, показаннями до операції з приводу вузлового зобу вважаємо:

I. Хірургічні:

- діаметр вузла (-ів) понад 3 см у жінок, 2 см - у чоловіків, що проявляеться місцевими симптомами;

- швидке збільшення вузла (-ів) більш ніж на 50\% за 6 - 12 міс;

- поява синдрому стискання та деформації органів шиі;

- шийно-загруднинне розташування вузла (-ів);

- наявність тиреотоксикозу на тлі вузла (-ів);

- косметичний дефект та наполегливе бажання пацієнта (як правило, онкомотивація).

II. Онкологічні: припущення про наявність раку ЩЗ за результатами цитологічного або ультразвукового (УЗД) дослідження, клінічних ознак (щільність, фіксація вузла, біль), наявність спадкового анамнезу щодо раку ЩЗ.

Показаннями до оперативного лікування з приводу ДТЗ були: тяжкий перебіг захворювання з виникненням специфічних ускладнень тиреотоксикозу, рецидивуючий перебіг захворювання, неможливість досягнення стійкої ремісії, непереносність тиреостатичної терапії, вели-

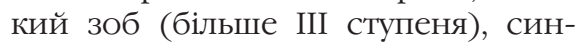


дром стискання, деформація органів шиї, косметичний дефект, наполегливе бажання хворого, припущення про наявність раку щз.

Всі хворі оперовані в плановому порядку після відповідної передопераційної підготовки, в стані природного або медикаментозного еутиреозу. 3 метою нормалізації гормональної активності ЩЗ, гемодинаміки і нервово-психічного статусу підготовку хворих до операції за наявності тиреотоксикозу проводили в ендокринологічному відділенні. У терапевтичному стаціонарі готували до операції пацієнтів з вузловим нетоксичним зобом, супутніми серцево-судинними захворюваннями. Визначали гормональну активність ЩЗ, титр антитіл до тиреотропного гормону, проводили УЗД, тонкоголкову аспіраційну біопсію ЩЗ під контролем УЗД. Під час операції проводили цитологічне дослідження мазка-відбитка зі зрізу вузла, а також його експрес-гістологічну діагностику. До операції і в ранньому післяопераційному періоді (в перші 3 доби) контролювали рівень $\mathrm{Ca}^{2+}$ та $\mathrm{P}^{5+}$ у крові, при змінах голосу або порушенні ковтання проводили моніторинг функції гортані (консультація отоларинголога).

Хворі оперовані під внутрішньовенною анестезією з штучною вентиляцією легень.

\section{РЕЗУЛЬТАТИ}

Обсяг оперативного втручання обирали залежно як від даних доопераційного клінічного, інструментального (УЗД, КТ) та цитологічного дослідження, так і інтраопераційної діагностики - макроскопічної оцінки ЩЗ, цито- та експрес- гістологічного дослідження (див. таблицю).
32000 р. при операціях на Щ3 застосовуємо хірургічний доступ за Кохером у нашій модифікації (пат. України 42165 А від 15.10.2011). При цьому верхній шкірно-підшкірнофасціальний клапоть 3 пересіченими та перев'язаними передніми яремними венами відшаровуємо до висоти стояння верхніх часток ЩЗ

Нижній клапоть виділяемо в тому самому анатомічному шарі до верхнього краю вирізки груднини. За довгої шиї і розмірах зобу до III ступеня претиреоїдні м'язи розводимо, за короткої шиї і великих розмірах малорухомої ЩЗ - пересікаємо.

3 приводу вузлового зобу ГТЕ виконана у 65,8\% хворих, ГТЕ, резекція прилеглої до перешийка частини контралатеральної частки ГТЕ, РК у 25,7\% (при розташуванні "підозрілого” в онкологічному аспекті вузла біля перешийка або з переходом на нього), СРЧ - у 6,4\%. У 4 (2,1\%) хворих за даними інтраопераційного цитологічного дослідження встановлений папілярний рак, виконана TE.

3 приводу багатовузлового зобу ТЕ здійснена у 74,5\% хворих. У 8 3 них за даними інтраопераційного цитологічного дослідження виявлені ознаки злоякісного процесу, збільшені і щільні лімфатичні вузли VI колектора шиї, виконані TE, центральна лімфодисекція шиї (ЦЛШ), у 23\% - ГТЕ, РК або СРЩ3.

3 приводу змішаного токсичного зобу ТЕ виконана у 63,3\% пацієнтів, ГТЕ, РК або СРЧ - у 36,6\%. 3 приводу тиреотоксичної аденоми оперовані 10 хворих, з них у 6 (60\%) - виконана ГТЕ, у 3 - ГТЕ, РК, в 1 - СРЧ. 3 приводу ДТЗ ТЕ виконана у $12(21,1 \%)$ пацієнтів, СРЩЗ - у 42 (73,7\%), ГТЕ, РК - у 3 (5,3\%).
За результатами заключного гістологічного дослідження, рак ЩЗ діагностований у 28 (4,6\%) хворих, оперованих з приводу вузлових форм зобу: папілярна карцинома - у 22, фолікулярна - у 6. ТЕ або ГТЕ виконана у 24 хворих, резекція щ3 - у 4. Усі пацієнти направлені в Обласний онкологічний диспансер для подальшого лікування.

\section{ОБГОВОРЕННЯ}

Починаючи 32007 р., ми перейшли на екстрафасціальну методику видалення (резекціiі) ЩЗ з застосуванням прецизійної техніки, візуалізацією НГН і прищитоподібних залоз, моніторингом збереження «структур ризику» під час оперативного втручання. Для запобігання травматизації зовнішньої гілки ВГН роздільно перев'язуємо судини біля верхнього полюсу частки ЩЗ під час іiі мобілізації, застосовуємо так званий «сліпий» спосіб, що попереджає травматизацію нерва, шляхом відтискання його від судин біля верхнього полюсу частки ЩЗ (пат. України 90201 від 12.05 2014). Застосування запроваджених методів мінімізуе частоту специфічних ускладнень при операціях на ЩЗ.

Одночасно, з огляду на онкологічний ризик та високу вірогідність виникнення рецидиву при застосуванні резекційних методик, ми віддаємо перевагу радикальним методам оперативного втручання: ТЕ - при багатовузловому зобі і ДТЗ, ГТЕ - при однобічному вузловому зобі. Економні резекційні методики залишені у минулому. У 2002 - 2006 рр. з приводу однобічного вузлового зобу ГТЕ виконана у 41,5\% хворих, ГТЕ, РК - у 43,9\%, СРЧ - у 14,6\%; багатовузлового зобу: ТЕ- у $28,8 \%$, ГТЕ, РК - у 44,2\%,

Оперативні втручання, виконані у $2002-2016$ рр.

\begin{tabular}{|c|c|c|c|c|c|c|c|}
\hline \multirow[b]{2}{*}{ Діагноз } & \multirow[b]{2}{*}{$\begin{array}{l}\text { Кількість } \\
\text { хворих }\end{array}$} & \multicolumn{6}{|c|}{ Кількість операцій } \\
\hline & & TE & $\begin{array}{c}\text { TE, } \\
\text { центральна } \\
\text { дисекція } \\
\text { шиї }\end{array}$ & ГTE & ГTE, PK & СРЩЗ & $\mathrm{CPY}$ \\
\hline Однобічний вузловий зоб & 187 & 4 & - & 123 & 48 & - & 12 \\
\hline Багатовузловий нетоксичний зоб & 322 & 240 & 8 & - & 46 & 28 & - \\
\hline Багатовузловий токсичний зоб & 30 & 19 & - & - & 9 & 2 & - \\
\hline Тиреотоксична аденома & 10 & - & - & 6 & 3 & - & 1 \\
\hline ДТЗ & 57 & 12 & - & - & 3 & 42 & - \\
\hline Разом ... & 606 & 275 & 8 & 129 & 109 & 72 & 13 \\
\hline
\end{tabular}

Примітка.

TЕ - тиреоїдектомія; ГТЕ - гемітиреоїдектомія; РК - резекція контралатеральної частки; СРЩЗ - субтотальна резекція щ3; СРЧ - субтотальна резекція частки Щз. 
СРЧ - у 30\%. Усім хворим з приводу ДТЗ здійснена СРЩЗ.

За період 2012 - 2016 рр. 3 приводу однобічного вузлового зобу ГТЕ виконана у 83,3\% хворих, ГТЕ, РК у 16,7\%; багатовузлового зобу ТЕ - у 94,8\%, ТЕ, ЦЛШ - у 5,2\%; ДТ3, ТЕ - у $75 \%$, ГТЕ, РК - у $25 \%$.

Операцію завершуємо контролем гемостазу, зрошенням рани 5\% розчином амінокапронової кислоти та дренуванням операційної рани двома хлорвініловими трубками з активною аспірацією і створенням в рані від'ємного тиску (пат. України 63286 від 10.10.2011). Накладаємо внутрішньошкірний косметичний шов. Дренажі видаляємо у 1-шу до- бу після операції, шви знімаємо на 4 - 5-ту добу.

Після операції гіпопаратиреоз виник у 12 (2\%) хворих (як правило, транзиторний), ушкодження поворотного нерва - у 8 (1,3\%). Більшість цих ускладнень виникли під час освоєння методики. Післяопераційного тиреотоксичного кризу не було.

Впровадження анатомічно орієнтованої прецизійної техніки на всіх етапах операції на ЩЗ дозволило, незважаючи на підвищення радикалізму втручання, досягти зменшення частоти специфічного ушкодження «структур ризику», уникнути таких ускладнень, як серома, гематома операційної рани, хвороба відшарованих клаптів. Всі пацієнти живі.

\section{висновки}

1. Екстрафасціальна методика видалення ЩЗ або ії частки забезпечуе візуальний контроль у зонах ризику, радикальність операції, мінімізує частоту специфічних ускладнень.

2. Прецизійна анатомічна хірургічна техніка $є$ обов'язковим компонентом оперативного втручання на щ3.

3. Визначальним у запобіганні специфічних післяопераційних ускладнень при операціях на ЩЗ є свідоме поєднання новітніх технологій і досвіду хірурга.

\section{REFERENCES}

1. Rybakov SI, Shydlovskyi VO, Komisarenko IV, ta in. Tyreoidna khirurhiia. Ternopil: HDMU; 2008. 424 s. [In Ukrainian].

2. Larin OS, Cherenko SM, Horobeiko MB. Shcho do vidpovidnosti taktyky likuvannia raku shchytopodibnoi zalozy $v$ Ukraini do yevropeiskoho konsensusu 2006 roku. Klinichna endokrynolohiia ta endokrynna khirurhiia. 2006;3(16):11-3. [In Ukrainian].

3. Osadchuk DV. Morfofunktsionalne obgruntuvannia vyboru obsiahu operatyvnykh vtruchan ta pisliaoperatsiinoi reabilitatsii u khvorykh na vuzlovyi koloidnyi zob (tezy). Ternopil, 2010. 20 s. [In Ukrainian].

4. Cherenko SM. Suchasni tendentsii v diahnostytsi ta likuvanni vuzlovoho zobu: dosvid kliniky u vyrishenni dyskusiinykh pytan. Klinichna endokrynolohiia ta endokrynna khirurhiia. 2002;1(1):7-9. [In Ukrainian].

5. Larin OS. Standartyzatsiia pidkhodiv do likuvannia vuzlovoho zobu na osnovi patohenetychno dotsilnykh ta efektyvnykh metodiv - vymoha chasu u suchasnii endokrynolohii. Klinichna endokrynolohiia ta endokrynna khirurhiia. 2002;3:109-16. [In Ukrainian].

6. Hegedus L, Bonnema SJ, Bennedbaek FN. Management of simple nodular goiter: current status and future perspectives. Endocr Rev. 2003;1(24):102-32.
7. Yermakova TV, Deikalo IM, Shydlovskyi OV. Khirurhichne likuvannia patolohii shchytopodibnoi zalozy z zastosuvanniam tekhnolohii LIGASURE. Klinichna endokrynolohiia ta endokrynna khirurhiia. 2015;2(50):37-40. [In Ukrainian].

8. Cherenko SM. Shliakhy poperedzhennia spetsyfichnykh uskladnen u khirurhii shchytopodibnoi ta pryshchytopodibnoi zaloz. Klinichna endokrynolohiia ta endokrynna khirurhiia. 2006;4(17):5-6. [In Ukrainian].

9. Palamarchuk VA, Cherenko SM, Laryn AS. Profilaktika spetsificheskikh khirurgicheskikh oslozhnenyi pri lechenii diffuznoho toksicheskoho zoba. Problemi endokrinnoy patolohii. 2003;2:47-51. [In Russian].

10. Klinichni protokoly vedennia khvorykh iz khirurhichnoiu patolohiieiu endokrynnoi systemy. Ukrainskyi naukovo-praktychnyi tsentr endokrynnoi khirurhii, transplantatsii endokrynnykh orhaniv i tkanyn MOZ Ukrainy. Ukrainska Asotsiatsiia Endokrynnykh Khirurhiv: Kyiv; 2011. 12 s. [In Ukrainian]. 